\title{
Ensuring safe working conditions during the rehabilitation of operated combined insulated rolled roofs
}

\author{
Vyacheslav N. CHERNOIVAN*1, Anna V. TORKHOVA ${ }^{1}$, and Nikolay V. CHERNOIVAN ${ }^{1}$ \\ ${ }^{1}$ Brest State Technical University, Brest, Belarus
}

\begin{abstract}
The recommended option for rehabilitation of operated combined insulated rolled roofs allows to reduce the cost of measures to ensure safe working conditions. The article proposes a construction solution similar to an inverted roof. In the proposed solution, the role of a vapor barrier is played by the repaired layers of the existing waterproofing layer to which the insulation board has been attached.
\end{abstract}

Keywords:rolled material, fire method, inversion roof.

\section{Introduction}

Combined insulated rolled roofs, all layers of which are sequentially laid on a supporting structure and covered with a waterproof carpet, make up more than $80 \%$ of the roofs of operated and erected residential and public buildings. in the Republic of Belarus. This is due to the following:

- in the mid-70s of the last century, industrial production of multi-hollow flooring made of precast reinforced concrete was established in the Republic of Belarus;

- significant (more than 15\%) savings in material and labor resources compared to attic roofs;

- relatively simple (compared to pitched roofs) construction technology.

However, after 3-5 years of operation in such roofs, due to the appearance of leaks, it was necessary to carry out routine repairs. This repair, as a rule, was reduced to the sticker of additional layers of rolled waterproofing material in areas of roof leaks $[5,8]$. It should be noted that in less than $10 \ldots 12$ years of operation, such roofs required major repairs $[2,7]$.

The results of field surveys of the technical condition of insulated roofs combined roll [5, 14], allowed us to conclude that the main causes leading to a significant deterioration in their performance (the appearance of leaks, reduced resistance to heat transfer) are:

- destruction of bitumen waterproofing layer by ultraviolet radiation (UV) in areas of the roof, where there is no protective layer;

- an increase in the moisture content of the material of the thermal insulation layer by 2.5-5.0 times compared to the values set [16];

- high vapor permeability resistance of bitumen-based insulating roll materials.

Recommended technologies for the rehabilitation of operated combined insulated rolled roofs are labor-intensive. They include: dismantling of the damaged rolled carpet, replacement or drying of a layer of moistened insulation material, repair of vapor barrier and installation of a new roof $[4-6,8]$. All these works are classified as high-risk works, as they are performed at altitude in cramped conditions using gas burners. The production of such works requires the development of safety measures for both those working at the facility and additional measures to ensure the safety of residents of the house under repair and objects located in the danger zone $[1,11,12]$.

*Corresponding author: E-mail address: vnchernoivan@list.ru (Vyacheslav N. CHERNOIVAN) 
Taking into account the above, we can conclude: rehabilitation of operated combined insulated rolled roofs with complete dismantling of all roof layers is a labor-intensive technological process that requires additional material and financial costs to create safe working conditions for workers, both workers and people and vehicles located in the danger zone.

Therefore, the development of technology for the rehabilitation of operated combined insulated rolled roofs without their major repairs (dismantling of existing layers) is an urgent problem [15].

\section{Review of publications on the subject under consideration (problem)}

The main goal in the development of safety measures is to prevent the influence of harmful and dangerous production factors on workers $[1,11,17]$. The analysis of scientific publications on the organization and production of works on the installation of new insulated combined rolled roofs, as well as their rehabilitation, allows us to draw the following conclusions. The following factors are decisive in the development of safety measures during the production of works:

- constructive solution of the roof;

- building materials used for its device;

- a list of preparatory and basic works that need to be performed;

- the accepted technology of work production.

Practically in all publications it is noted that the technology of the device of new combined roofs is a complex technological process, including a large range of manual operations performed at height in cramped conditions. The use of rolled surfaced materials based on bitumen mastic as a vapor barrier and waterproofing carpet significantly complicates the safety of work on their sticker:

- works are carried out by fire method using gas burners (open flame) $[6,8,14]$;

- propane-butane cylinders (explosive substance) are located at the insulator's workplace (roof), which creates additional difficulties in ensuring safe working conditions [1, 11, 12].

Practice shows that the main problem in the rehabilitation of combined insulated roofs is the technology of restoration (repair) of the vapor barrier layer. High-quality work on the restoration of the vapor barrier layer is possible provided that all the layers located above are completely dismantled: a water-insulating carpet, a leveling screed, a layer of thermal insulation. This is a very time-consuming technological process. According to calculations, the labor intensity of dismantling $10 \mathrm{~m} 2$ of the area of all layers of the roof is more than 150 people-h [9, 10]. In addition dismantled carpet waterproofing bitumen mastic must be disposed of in special storage facilities (landfills), which also requires additional costs (transportation etc.) [12].

Organization of works on dismantling of the screed and insulation also requires additional measures to ensure environmental standards (the level of airborne dust, etc.) $[1,11,12]$.

\section{Research results and their discussion}

Analysis of research results $[2,4-6,8,13]$ allows us to draw the following conclusions. The massively applied technology of rehabilitation of operated combined insulated rolled roofs is a labor-intensive technological process including: dismantling of the damaged rolled carpet, replacement or drying of a layer of moistened insulation material, repair of vapor barrier, etc. $[4,5,8]$. Almost all work refers to high-risk work (performed at height, in cramped conditions with the use of gas burners). The performance of such works requires the development of additional security measures, both for residents of the house under repair and nearby facilities.

Taking into account the above, we can conclude: rehabilitation of operated combined insulated rolled roofs with complete dismantling of all roof layers is a labor-intensive technological process that requires additional material and financial costs to create safe working conditions for workers, both workers and people and vehicles located in the danger zone.

Therefore, the development of technology for the rehabilitation of operated combined insulated rolled roofs without their major repairs (dismantling of existing layers) is an urgent problem. 


\section{Presentation of research results}

The analysis of the design solutions recommended for mass use of combined insulated rolled roofs allows us to conclude that it is advisable to adopt the design of an inversion roof as a basis for the development of an effective technology for the rehabilitation of operated insulated combined roofs [3].

To perform the rehabilitation of the operated combined insulated roof, the following design solution is proposed (Fig. 1).

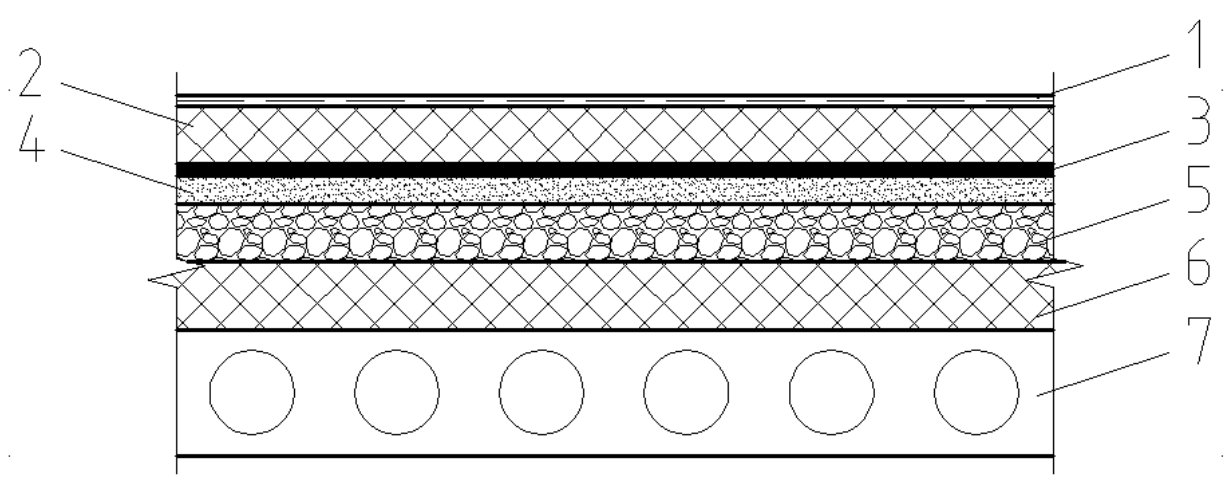

Figure 1. Recommended structural solution of the roof for rehabilitation:

1 - water-insulating carpet made of PVC membrane; 2 - thermal insulation layer of super-rigid mineral wool slabs (according to the calculation); 3 - rolled water-insulating carpet (existing); 4 - cement-sand screed (existing); 5 - layer of expanded clay gravel along the slope (existing); 6 - layer of thermal insulation (existing); 7 - reinforced concrete multi-hollow coating plate (existing)

The recommended design solution is similar to an inversion roof. In the proposed solution, the role of vapor barrier will be performed by the repaired layers of the existing waterproofing carpet, to which the slab insulation will be attached.

To increase the service life of the waterproofing carpet without repair, to ensure the safe technology of fastening the waterproofing carpet to the base, it is recommended that the waterproofing carpet be made of PVC membrane.

Technology of work production. Rehabilitation of the combined insulated roof includes the following technological processes: repair of the leveling screed; repair of the existing waterproofing carpet; installation of a thermal insulation layer of mineral wool slabs; fixing of the PVC membrane on the plate insulation.

The technology of repair of leveling screed and rolled waterproofing carpet is described in detail in [5, 8].

Upon completion of the repair of the waterproofing layer, the installation of a layer of thermal insulation is started. The thermal insulation layer is made of mineral wool slabs with a bituminous mastic attachment [3]. The recommended technology of work production is described in $[5,8]$.

At the end of the thermal insulation works, a waterproof carpet made of PVC membranes is attached. The ability of PVC membranes to pass water vapor, eliminates the appearance of bloating (air bags) when moistening the insulation layer. Fastening of the membrane to the base is carried out by heat-welded method.

The technological sequence of work on fixing the membrane to the base by the heat-welded method is described in $[6,8]$.

\section{Conclusions}

The results of field studies have shown that the main reason for the deterioration of the performance characteristics of insulated combined roofs is the destruction of the vapor barrier layer, leading to moisture insulation.

The constructive solution proposed by the authors of the publication and the technology of rehabilitation of combined insulated rolled roofs allows to ensure safe conditions for construction work and comfortable living conditions without dismantling the structural elements of the existing roof. 


\section{References}

1. Baranashnik, A. B., Lipen, L. I. \& Pilipenko, N. S. Labor Safety 407 (Amalfea LLC, Minsk, 2018).

2. Baryłka, A. \& Obolewicz, J. Safety and health protection (s and hp) in managing construction projects. Inżynieria Bezpieczeństwa Obiektów Antropogenicznych 1 (2020).

3. Building Codes 5.08.01-2019. Roofings. Minsk, Publishing House of Ministry of Architecture and Construction of the Republic of Belarus, 24 2020.

4. Chernoivan V. N.and Leonovich, S. N. \& Chernoivan, N. V. To the Estimate of the Engineering State of the Maintained Combined Roll Roofing. Construction Science and Technology 3, 47-51 (2011).

5. Chernoivan, V. \& Chernoivan, N. Rehabilitation of Combined Insulated Rolled Roofs. Restoration of the Operational Characteristics of Combined Insulated Rolled Roofs During Their Repair 93 (LAP LAMBERT Academic Publishing, Germany, 2014).

6. Chernoivan, V., Leonovich, S. \& Chernoivan, N. Technology of construction production. Information and Computing Center Ministry of Finance of the Republic of Belarus, 576 Minsk, 2019.

7. Eropov, L. Features of Work of Roofs from the Rolled Roofing Materials and Approaches to Their Choice. Technical Sciences - from Theory to Practice 11, 74-78 (2012).

8. Leonovich, S., Chernoivan, V. \& N.V., C. Effective technologies for the construction of buildings and structures 243 (BNTU, Mińsk, 2019).

9. Norms of Labor Costs for Construction, Installation and Repair and Construction Work. Collection 20. Repair and Construction Works. Issue 1. Buildings and Industrial Structures. Minsk, Publishing House of Ministry of Architecture and Construction of the Republic of Belarus, 224 2009.

10. Norms of Labor Costs for Construction, Installation and Repair and Construction Work. Collection \%. Roofing Works. Minsk, Publishing House of Ministry of Architecture and Construction of the Republic of Belarus, 41 2009.

11. Obolewicz, J., Baryłka, A., Jaros, H. \& G., G. A map of knowledge and its importance in the life cycle of a constructiom object. Inżynieria Bezpieczeństwa Obiektów Antropogenicznych 2 (2020).

12. Rules on labor Safety During Construction Work 52 (Publishing House of Ministry of Architecture and Construction of the Republic of Belarus, Mińsk, 2019).

13. Rumyantsev, B. M. \& Zhukov, A. D. Insulation Systems for Building Structures, MGSU. 640 Norm. Moscow, 2014.

14. Sidenko D.A.and Belevich, V. Durability of Flat Rolled Roofs. Industrial and Civil Engineering 8, $20-21$ (2004).

15. Technical Code of Common Practice 45-1.04-37-2008, Inspection of Building Structures of Buildings and Constructions. Procedure. Minsk, Publishing House of Ministry of Architecture and Construction of the Republic of Belarus, 392014.

16. Technical Code of Common Practice 45-2.04-43-2006*. Building Heating Engineering. Building Rates of the Designing (Publishing House of Ministry of Architecture and Construction of the Republic of Belarus, Mińska, 2015).

17. The Law of the Republic of Belarus, On Labor Safety 